\title{
Processes at Water Intake from Mountain Rivers into Hydropower and Irrigation Systems
}

\author{
Nikolai Vatin ${ }^{1, *}$, Nikolai Lavrov ${ }^{1}$ and Gennadi Loginov ${ }^{1}$ \\ ${ }^{1}$ St. Petersburg State Polytechnical University, Politekhnicheskaya, 29, Saint-Petersburg, 195251, \\ Russia
}

\begin{abstract}
In paper, researches of riverbed and hydraulic processes at the water intake from mountain rivers are observed. Classification of designs of the mountain water intake structures, based on continuity signs is offered. Perfecting of base designs of water intake structures of a mountain-foothill zone and means of their hydraulic automation is carried out. The technological, theoretical and experimental substantiation of parameters of basic elements of these designs with a glance of hydromorphometric characteristics of the mountain rivers is given. Complex hydraulic researches of kinematic characteristics and carrying ability of a two-phase stream on water intake structures are executed. Bases of a technique of engineering calculation of the offered designs of water intake structures and the recommendation of their designing and maintenance in various hydrological regimes are developed.
\end{abstract}

\section{Introduction}

Now designing and maintenance of water intake structures on the mountain rivers is spent without the sufficient account of demands of creation of necessary riverbed and hydraulic processes on water intake sections that is one of the principal causes of idle times, damage and crashes of constructions. Therefore, there is a necessity of an estimation of rationality of existing lay-out drawings of water intake and regulation structures with definition of their deficiencies. It demands conducting theoretical and experimental researches to raise of characteristics of process of the water intake, by the management of two-phase streams and regimes of formation of bed landforms. In it, the urgency of the given work, devoted to studying and working out of possibilities of use of energy of water streams on sections of regulated riverbeds and in pools of low-head dam water intake structures, consists.

\section{Experimental program}

The purpose of researches is perfection of the theory, methods of researches and rated validation of necessary characteristics of riverbed and hydraulic processes at the water intake from the mountain rivers. It allows to devide out involved material resources at designing, building and to raise reliability of low-head dam water intake structures during

* Corresponding author: vatin@mail.ru 
service. The analysis of characteristics of riverbed and hydraulic processes for the purpose of performance of the basic technical requirements and engineering operations at the water intake, presented in works S. Elsden [1, 2], N. Kanthack [2], R. Krohmer [3], S.T.Altunin [2], K.F.Artamonov [4], N.F.Danelia [2], I.S.Rumjantsev [5], I.I.Levi [2], JA.V.Botchkarev [1], B.I.Melnikov [2], A.S.Ofitserov [1], A.I.Rohman [1], I.K.Rudakov [1], G.V.Sobolin [2], A.V.Filonchikov [6] and other researchers, is made.

Authors of paper prove classification of existing designs low-head water intake structures [7].

This classification defines communication of known lay-out drawings by using of previous rational solutions for working out of the subsequent advanced configurations of structures.

For perfection of the water intake process the following processing methods have been gated out:

- creation of the transverse circulation of water on a section of approach riverbed by means of curvilinear regulated section;

- increasing intensity of the transverse circulation of water before a water intake by creation of the local circulating screw with the help of sediment-protective threshold;

- water selection realisation during the warm period of year from surface horizons of a stream and ground removal of sediments;

- water selection during the winter period from near-bottom horizons of a stream with surface removal and dump ice brash formations;

- creation of depths of water stream which necessary for generation of resistant hydraulic forms before elements of a structure;

- maintenance of the smooth approach of water to devices of the water intake structure and stream outlet;

- definition of a position and parameters of devices of a heading range taking into account conditions of creation of active zones of traffic of hard spots of river sediments in approach regulated riverbed;

- maintenance of rated heads in the upper pool of the structure and stabilization of the water discharge, submitted to outlet canals with use of means of hydroautomatics;

- at a high water simultaneous removal of excesses of water and a driftwood on all front of the water intake structure and carrying sediments - through river bay apertures is provided;

Performance of these conditions allowed execution during researches the matching of principles of configuration of advanced designs of water intake structures with existing techniques of designing of devices of water intake from the mountain rivers.

Observing the arrangement of a curvilinear approaching riverbed before the heading gate of the water intake structure as the first line of protection against sediments, known representations about the reasons of origin of the transverse circulation have been analysed. M.A.Dementyev, M.V.Potapov, N.F.Danelia, Cecen K, Schucky A, Zolezzi G., Seminara G., Solari. L., $[2,8,9,10,11]$ as the reasons of formation of the radial secondary currents considered the inertia force - centrifugal.

A.J.Milovich [12] defined as the reason of cross-flows in the radial direction a pressure difference in cross-sections of curvilinear parts.

Passing from the qualitative description to quantitative characteristics, the mathematical model presenting occurring hydraulic processes on curvilinear parts of the rivers has been observed: 


$$
\left.\begin{array}{l}
Q_{b i}=Q_{b(i-1)}+Q_{R} \Theta_{i}-Q_{g r . i} \\
\Theta_{i}=\frac{\cos \varphi_{i-1}-\cos \varphi_{i}}{1-\cos \varphi} \\
Q_{g r . i}=Q_{g r .(i-1)}+\int_{0}^{L_{b i}} \omega_{i} C_{i} \sqrt{R_{i} \Delta J} d l \\
\omega_{i}=k_{i} d l \\
d_{i}=\sqrt{\frac{4 Q_{b i}}{\pi v}}
\end{array}\right\}
$$

Where $Q_{R}$ - water discharge in a river; $Q_{b i}$ - water flow moving in a rotating cone; $\varphi_{i}$ angle between entrance cross-section of a curvilinear part and observed $i$ - cross-section; $Q_{g r . i}$ - charge of ground currents of the water separating from a cone-shaped stream from its beginning to observed cross-section; $\Theta_{i}$ - coefficient considering a share of a projection of the observed section in the general projection of a concave shore, on a plane placed in the beginning of curvature of a riverbed; $\omega_{i}$ - cross-sectional area of a near-bottom stream separating from cone-shaped roll; $k_{i}$ - vertical size of a ground stream in observed crosssections; $R_{i}$ - design quantity of hydraulic radius; $d_{i}$ - diameter of cone-shaped roll; $v$ average speed of water in cone-shaped roll; $C_{i}$ - coefficient of Shezi for movement of nearbottom currents; $\Delta J$ - increment of the transverse slope of a free surface of a water stream as a result of inertial force act at climb of a stream on a concave shore.

Using the theory of dynamic interacting of solids and a liquid, offered by A.J.Milovich [12], the connection of the longitudinal $\mathrm{Vl}$ and transverse $\mathrm{Vt}$ components of circulating roll with speed of water movement in the upper pool of a structure and a contour of an external surface of sediment-protective threshold has been defined in an aspect:

$$
\frac{V_{t}}{\sin \gamma}=\frac{V_{l}}{\cos \gamma} \rightarrow \varphi=\operatorname{arctg} \frac{V_{t}}{V_{l}}+\pi n
$$

Taking this into account, the system of the equations has been developed for calculation of co-ordinates of a planned configuration of circulating sediment-protective threshold [2] and the planned contour of an external surface of sediment-protective threshold, presented on fig. 1 is gained.

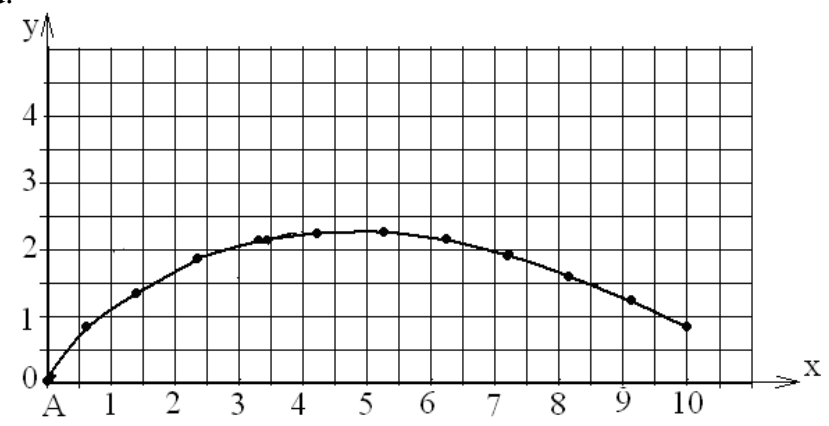

Fig. 1. Contours of an external surface of sediment-protective threshold. 
By consideration of alternatives of increase in carrying ability of a sluiceway tract [13, $14,15]$, us the arrangement of a horizontal peak on the lower edge of the gate of sluiceway tract was offered. By transformation of the Bernoulli's equation made for cross-sections I-I and II-II (fig. 2), the formula for calculation of speeds of a water stream under a horizontal peak is gained.

$$
V_{2}=\frac{1}{\sqrt{\alpha_{1}}} \sqrt{2 g\left(H_{R}-\varepsilon a-h_{\omega}\right)-\alpha_{1} V_{1}^{2}+\frac{2\left(p_{1}-p_{2}\right)}{\rho}}
$$

Where $H_{R}$ - the water depth in front of the device; $p_{1}$ and $p_{2}$ - pressure on a stream free surface in cross-sections; $\rho$ - liquid density; $g$ - free fall acceleration; $\alpha_{l}$ - coefficient, considering irregularity of stream velocity distribution in initial cross-section; $\varepsilon$ coefficient of jet contraction of a stream; $h_{\omega}$ - stream energy loss on a length of a nozzle.

It allowed to create pressure decline in a near-bottom layer of two-phase stream with increase in speeds of water under a horizontal peak (see fig. 2), and secured raise of removed volumes of sediments.

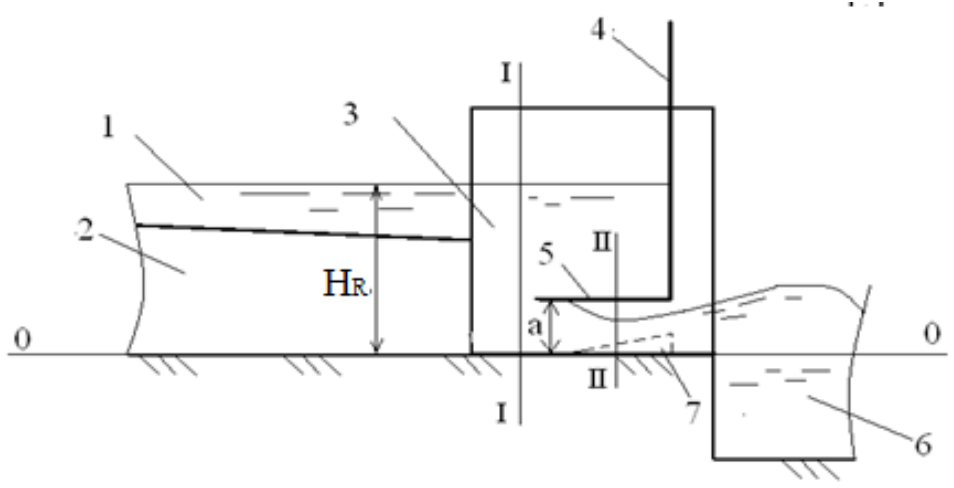

Fig. 2. Scheme of a horizontal peak on the lower edge of the gate of sluiceway tract: 1 - upper pool; 2 - circulating sediment-protective threshold; 3 - sluiceway tract; 4 - flat gate; 5 - horizontal peak; 6 offtake riverbed; 7 - bottom insert.

Preliminary results of laboratory researches of the gate with a horizontal peak confirmed raise of carrying ability of water stream in a sluiceway tract of water intake structures.

Because of transformation of momentum equation, the formula for definition of the charge of sediments has been gained as [2]:

$$
G=\frac{2 \Delta K-\rho g b_{s t}\left(2 h_{2} J \times l_{a c}+J^{2} l_{a c}^{2}\right)}{2 \alpha^{\prime \prime}\left(\rho_{s}-\rho\right)\left(v_{2}-v_{1}\right)}
$$

Where $\Delta K$ - an increment of a momentum of weight of the two-phase fluid stream removed through a sluiceway tract, accumulating sediments at length $l_{a c}$ in unit of time; $b_{s t}$ width of sluiceway tract, $\rho$ and $\rho_{s}$ - density of water and carrying sediments; $J$ - hydraulic slope, $\alpha^{\prime \prime}$ - the coefficient of the amount of movement; $v_{1}$ and $v_{2}$ - movement speeds of carrying sediments in an initial and final range of a tract.

The aspect of the equation (4), allows to define that carrying ability of a water stream increases at growth of value of change of a momentum, and decreases owing to growth of values of following values: width and depths of a stream on length of a sluiceway tract; lengths of a sluiceway tract, density of corpuscles of sediments. Considering these factors, 
arrangement of a ground insert with an adverse slope at the bottom of a sluiceway tract (fig. 3) was offered.

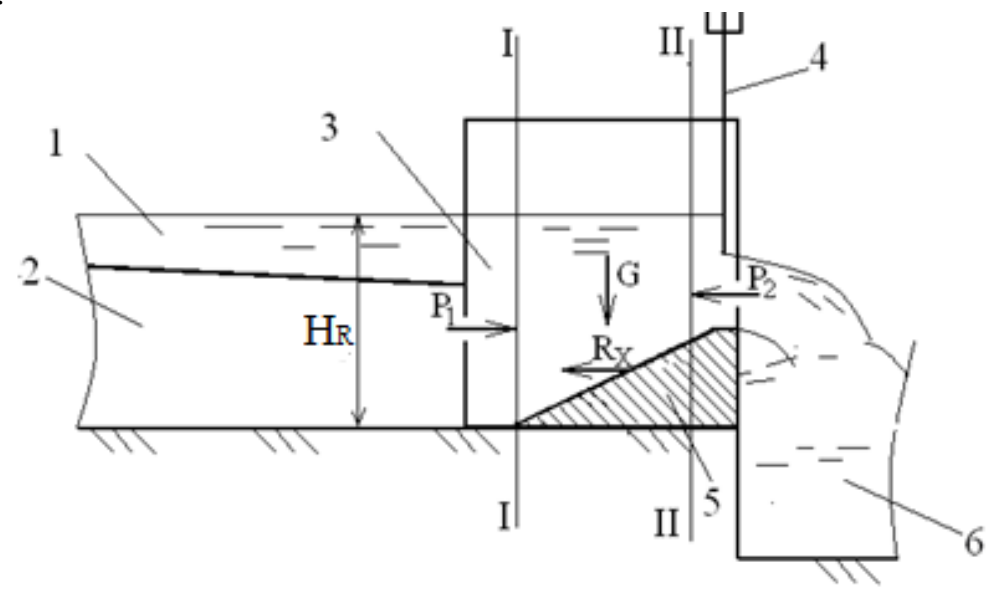

Fig. 3. Scheme of disposing of a ground insert in a sluiceway tract: 1 - upper pool; 2 - sedimentprotective threshold; 3 - sluiceway tract; 4 - gate of a sluiceway tract; 5 - ground insert; 6 - offtake riverbed.

For perfection of methods of management of riverbed and hydraulic processes at the water intake with the account of hydro-morphometric features of the mountain rivers on the basis of theoretical and modelling researches three designs of low-head dam water intake structure have been developed (fig. 4): Water intake structure for derivational river plants (patent KR № 607, 2003), Water intake structure for the mountain rivers (patent KR № 920, 2006, Water intake structure from the mountain rivers (the patent of the Russian Federation for useful model №133537, 2013). Elements used in their design and devices allow to create necessary hydraulic forms in a water intake zone.

On three experimental installations in KRSU complex laboratory researches of hydraulic processes at the water intake from the mountain rivers in scale from 1:7 till 1:25 have been executed. Methods of carrying out of physical modelling of two-phase streams (water, sediments) were based on I.I.Levi's recommendations, M.A.Mihalev [16], A.B.Veksler [17], based on conditions of observance of the kinematic similarity. At the first stage of experiments the rational sizes of three-section broken in plan sediment-protective threshold (fig. 4a) have been defined. Criterion was allowable value of hit of sediments in offtake canal. Investigating throughput of four-section broken in plan sediment-protective threshold (fig $4 \mathrm{~b}$,), function for definition of discharge coefficient of such surface spillway has been gained:

$$
m_{4 c . n}=-0,0281\left(\frac{H_{s p t}}{C_{s p t}}\right)^{2}+0,171 \frac{H_{n p}}{C_{n}}+0,1277
$$

This function is gained for a relative average head of $H_{s p t} / C_{s p t}=1,3 \ldots 3,2$, where $H_{s p t}$ an average head value, $C_{s p t}$ thickness of sediment-protective threshold wall.

By results of experimental researches of a sluiceway tract it has been defined that for the least capture of carrying sediments in water intake chamber10 the relative height of intermediate pier 7 (see fig. 4) between a river bay and sluiceway tract should be equal $h_{i p} / H_{R}=0,743 \ldots 94$. Here $h_{i p}$ - height of an intermediate pier, $H_{R}$ - depth of water in the river before a water intake gate. 

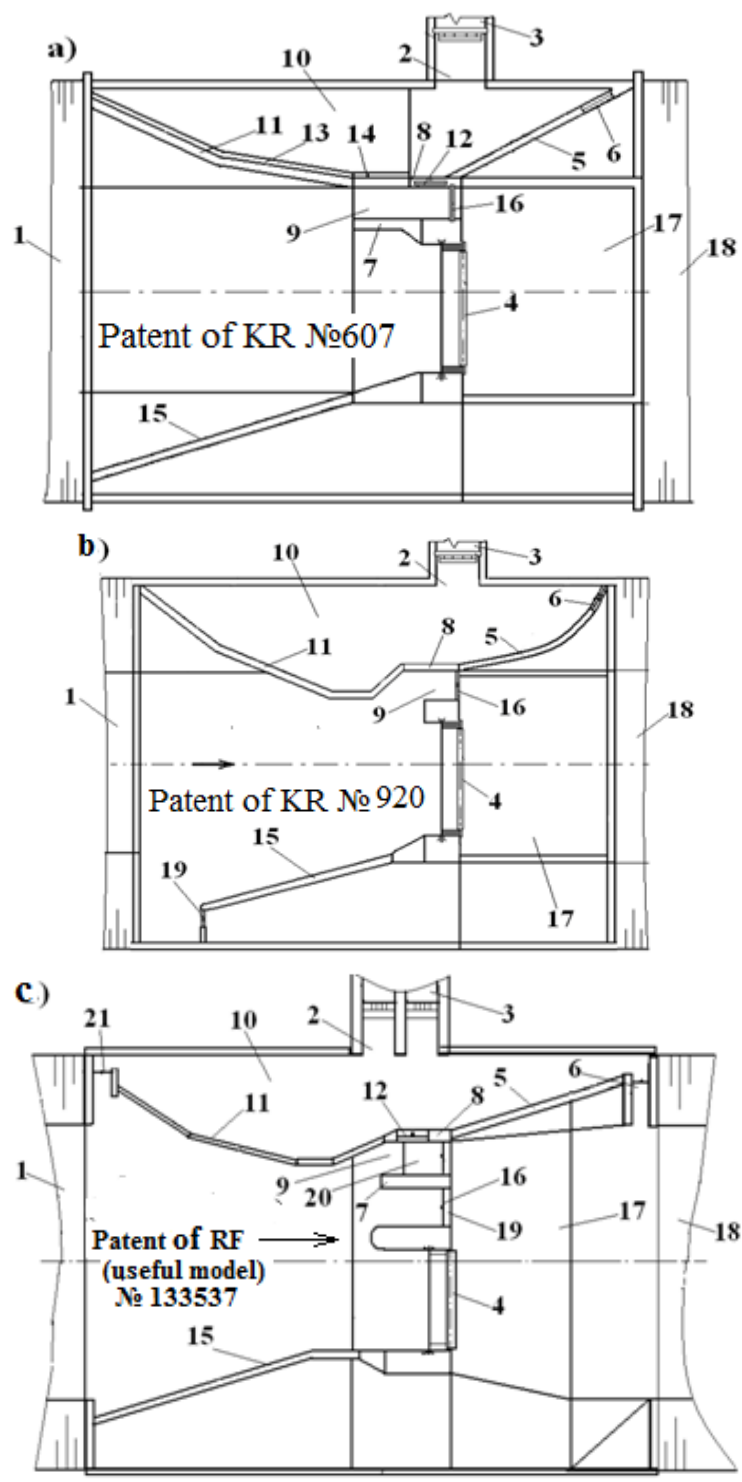

Fig. 4. Layout drawings of offered water intake structures: 1 - approaching riverbed; 2 - water receiver 3 - offtake canal; 4 - automatic gate of level of the upper pool; 5 - autosurface spillway of the water intake chamber; 6 - removal aperture; 7 - intermediate pier; 8 - dividing wall; 9 - sluiceway tract; 10 - water intake chamber; 11 - broken in plan circulating sediment-protective threshold; 12 aperture of the winter water intake; 13 - inner edge of a threshold; 14 - inset parts for stoplog; 15 autosurface spillway of upper pool. 16 - twin gate; 17 - hearth; 18 - offtake riverbed; 19 - additional washing aperture; 20 - ground insert; 21 - upper water intake aperture.

Maintenance of a necessary (command) water level in the upper pool of offered types of water intake structures is realized by means of known designs of automatic gates 4 of hydraulic action [1].

Carrying out the analysis of means of hydraulic automation of process of water supply in an offtake canal, the new design of the stabilizer of a water discharge of section parabolic box-shaped gate type (SPBG) has been developed which scheme is shown on fig. 5. 

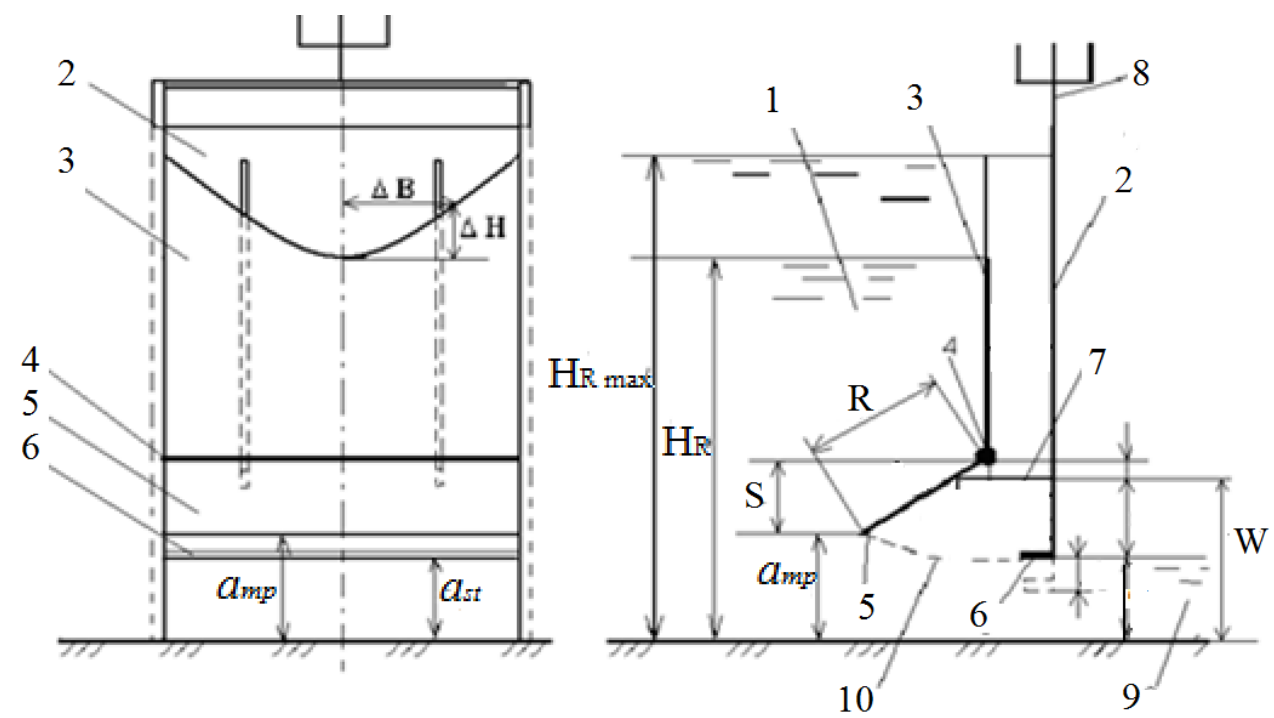

Fig. 5. Designed scheme of SPBG: 1 - upper pool; 2 - flat gate; 3 - head wall; 4 - hinge; 5 - rotary plate; 6 - horizontal peak; 7 - interacting rod; 8 - gate lifting screw; 9 - downstream; 10 - jet contraction path; 11 - path of displacement of the lower edge of the gate at regulating.

Distinctive features of the stabilizer are:

- for exploitation in the conditions of driftwood and trash transport a head wall 3 of discharge stabilizer are arranged separately from the flat gate 2 that allows to make its installation in water receiver before high water passage;

- to raise the accuracy of stabilization of the charge the heckle of the head wall 3 has not the step shape, as at its analogues [1], but the form of parabola which is carried out on the co-ordinates counted by formula [2]:

$$
\Delta B=\frac{\mu_{r p} a_{m p} B \sqrt{2 g\left(H_{R}-a_{s t}\right)}}{\mu_{r p} a_{m p}(B / \Delta B-2) \sqrt{2 g\left(H_{R}+\Delta H-a_{s t}\right)}+2 \mu_{h p} a_{s t} \sqrt{2 g\left(H_{R}+\Delta H-a_{s t}\right)}}
$$

Where $\mu_{r p}$ and $\mu_{h p}$ - water discharge coefficients at the outflow under rotary plate and a horizontal peak; $a_{m p}$ and $a_{s t}$ - opening of a moving plate and the stabilizer; $B$ - width of the water receiver; $H_{R}$ - designed depth in the upper pool. It has been experimentally defined that the lapse in water discharge stabilisation at various opening of gate SPBG does not exceed $4 \%$. It is confirmed, that the given design of the discharge stabilizer can be used as the water-measuring device.

After definition of rational parameters of sediment-protective elements of water intake structures, we spent a number of modelling researches on perfection of technical characteristics of the devices serving for the winter water intake.

In the course of modelling researches (fig. 6) with a glance of winter hydrological regime of the mountain rivers and deficiencies of the organisation of the winter water intake on the existing water intake structures detected during our researches [1] and researches by A.V. Shipilov [17], the advanced layout drawing of the water intake structure for the mountain rivers (WISMR - 2) is developed. 


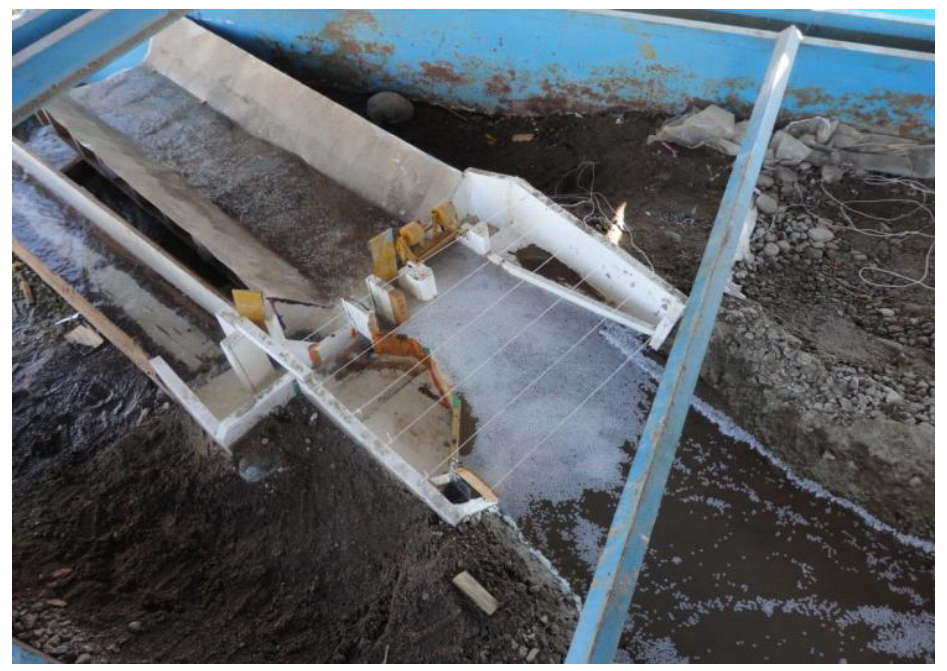

Fig. 6. Model of water intake structure for the mountain rivers of type WISMR - 2 in winter regime of maintenance.

According to the maintenance circuit design during the winter period for the developed configuration of the water intake structure water levels in the upper pool manually downgraded to a level of a horizontal heckle of sediment-protective threshold $[18,19]$. It is made for increasing of superficial speeds of a stream in ice-brash removal tract. Water selection to the water intake chamber is spent from near-bottom layers of a stream through the aperture of the winter water intake 12 (see fig. 4), and also from under the gate of the upper water intaking aperture 21 (fig. 4b). Ice-brash formations which arrive on an approach riverbed, are removed in the downstream through an upper surface of a ground insert 20 at a raising of the gate of the basic sluicing tract 9 and through a heckle of the put down twin gate 16 of additional sluicing tract 19 (fig. 4c). Mathematical modelling of some processes of the winter water intake from the mountain rivers has been executed by A.V.Shipilov [16] and matched with results of our experiments.

Researches of seasonal hydrological regimes influence on change of a landform of a bottom in the upper pool low-head dam water intake structures are executed. Also on model have been studied the conditions at which occurs sedimentation of the water intake structure downstream. Studying of kinematic characteristics and carrying ability of a twophase stream on investigated water intake structures in various regimes of maintenance [1] is spent.

For the purpose of raise of carrying ability of a stream in structure approaching riverbed, before the winter regime of maintenance, it was recommended to make partial washing of the upper pool on the technique approved on physical models [2].

The designed water intake structure for diversion hydropower plants (WIS for DHPP) was introduced in 2008 at reconstruction of the hydrosystem of Issyk-Ata HPP in Kyrgyzstan and at construction of a diversion HPP-3 on Merke river in Kazakhstan in 2010. On the basis of field research, taking into account the recommendations of [19, 20], at the facilities of the industrial implementation of efficiency and effectiveness for the water intake structure diversion hydropower plants on small mountain rivers $[1,2]$ confirmed. The deficiency of their exploitation is an adjournment of a prism of river sediments in the upper pool of water intake structure on Merke river and transport of superfluous quantity of ice-brash in the diversion canal of Issyk-Ata HPP.

Detected deficiencies have been considered in 2013 at working out of layout drawing of WIS for DHPP -2 in project of small HPP on the river Usek in Almaty area of Kazakhstan. 


\section{Conclusion}

Conducted researches of hydraulic and riverbed processes of the water intake and calculations of technical and economic efficiency on the specified installations of an industrial implementation confirm expediency of use of the developed structures at the water intake from the mountain rivers in hydropower and irrigational systems. On the basis of carried out researches bases of a technique of engineering calculation of the offered designs of water intake structures and the recommendation about their designing and maintenance in various hydrological regimes [1] are developed.

\section{References}

1. N.P.Lavrov, Hydraulic structures for small hydropower engineering of mountain and foot-mountain area (KRSU, Bishkek, 2009)

2. G.I. Loginov, Gidrawlicheskie prozessy pri wodozabore iz gornych reck (KRSU, Bischkek, 2014)

3. R. Kromer, Gidrosoorugenija, 3, 11-18 (2009)

4. K.F. Artamonov, A.N. Kroschkin Voprosy gidrotechnicheckoi klassifikacii ruslovych uchastkov i gidrometrii gornych reck, Morfologia rechnych rusel i ich modelirovanie (Gidromteoizdat, Leningrad, 1972)

5. I.S. Rumjanzev, R. Kromer, Prirodopribligennoe vosstanovlenie i expluatacia vodnych objektov (MGYP, Moscow, 2001)

6. A.V. Filonchikov, Proektirovanie avtomatizirovannych vodozabornych uzlov na gornych reckach (Frunze, 1990)

7. G.I. Loginov, N.P. Lavrov, Klassifikacia vodozabornyx soorugenii. Materialy VIII mezinarodni vedecko-prakticka conference "Dny vedy" po sekcich "Technicke vedu" (Education and Science, Praha, 2012)

8. G. Zolezzi, J. Fluid Mech., 438, 183 - 211 (2001)

9. A. Schucky, Thans. Amer. Soc/ Civ. Engr., 115, 49 (1950)

10. N. Reidar, B. Olsen, Numerical Modelling and Hudraulics, Department of Hudraulic and Environmental Engineering the Norwegian University of Scienee and Technology

11. G. Zolezzi, R. Repetto, M. Tubino, M. Toropov, M. Serafini, Mathematical modeling of silting in Kugart river, Kyrgyzstan, River Costal and EsturineMorphodynamics: RCEM 2007 - Dohmen-Janssen \&Hulscher (Taylor \& Francis Group, London, 2008)

12. A.J. Milovich, Teoriya dinamicheskogo vzaimodeistviya tel i gidkosti. Izdanie - 2, ispravlennoe $i$ dorabotannoe (Gos. izd-vo literatury po stroitellstvu i architecture, Moscow, 1955)

13. Ch. C. Edson, Civil Engineering, Engineer's Notebook, 1654, 64-65

14. I.R.D. Francis, Proc. Roy Soc. L, 332, 443-471 (1973)

15. P. J. Kerssen, A. Urk, J. Hydr. Engrg., ASCE, 112(7), 641- 656 (1986)

16. M.A. Michalev Fizicheskoe modelirovanie gidravlicheskix yavlenii (isd. Politech. unta, $\mathrm{SPb}, 2012)$

17. L. Svatovskaya, A. Sychova, M. Sychov, V. Okrepilov, MATEC Web of Conferences, 53, Article Number 01023 (2016)

18. J. Giesecke, E. Mosonyi, WasserkraftanlagenPlanung, Bau und Betrieb4., aktualisierte und erweiterteAuflagemit 368 Abbildungen Springer-Verlag (Heidelberg, Berlin, 2005)

19. S. Skiena, The Algorithm Design Manual: 2nd Edition (Springer, New York, 2008)

20. T. Abbasi, S.A. Abbasi, Renewable and Sustainable Energy Reviews, 15, 2134-2143 (2011) 